\title{
Transportation, access to safe sanitation, and number of midwives and economic growth in districts in Indonesia
}

\author{
Wilson Rajagukguk ${ }^{1, *}$ \\ ${ }^{1}$ Universitas Kristen Indonesia, Jakarta
}

\begin{abstract}
Transportation is the main driver of all economic sectors in a country. It boosts economic activity and promotes a commodity and geographical area. As a maritime country with more than 17,000 islands Indonesia needs to connect through transportation so that economy can grow and commodities across regions can be traded and commercialized. Other factors that affect economic growth are health personnel and infrastructure development. This study is aimed to investigate the association between transportation, access to sanitation, and health personnel availability and economic growth in districts (kabupaten/kota) in Indonesia. The data used came from the Indonesia Database for Policy and Economic Research (INDO-DAPOER) of the World Bank that covered 331 districts in Indonesia in 2005, 2008, and 2011. The dependent variable was the total GDP excluding oil and gas, while the independent variables were the villages with asphalt road, household access to safe sanitation, and the number of midwives. The results of the study indicate that in districts in Indonesia higher GDP was associated with higher percentage of village with asphalt road, higher percentage of households with access to safe sanitation, and higher number of midwives.
\end{abstract}

\section{Introduction}

Progress and development can be defined as an improvement in welfare of an economy through adequate social, politic, and economic condition. The expected outcome can be an enhancement and improvement in human capital in quantitative and qualitative form, such as income, health, or education, and also in physical capital, such as the availability of transportation, public services, and telecommunication. The industrial policy can be improved through an effective infrastructure management that then improves the competitiveness of a country $[1,2,3]$.

There are a number of factors that can affect economic growth and competitiveness. These include institution, infrastructure, health, basic education, the availability of technology, and market size. Infrastructure factors are mainly supported by the availability of road, railroad, air transport, and electricity supply. Infrastructure is the key factor in

\footnotetext{
*Corresponding author: wrajagukguk@yahoo.com
} 
increasing income level and presents important means to policy makers and business leaders in formulating economic improvement and institutional reformation policies [4].

It is difficult to imagine a developed country and a modern world without transportation, telecommunication, energy, water, health, housing, and housing facilities. These infrastructures play a crucial role in promoting economic growth and thus reduce economic disparity and poverty in a country. Better education, health, water and sanitation, road network, and electricity access to the poor are needed for an economic justice and social empowerment. Infrastructure investment in transportation, such as roads, railways, ports, and civil aviation, energy and power, irrigation, watersheds, hydroelectric works, scientific research and training, markets and warehousing, communications and informatics, education, health, and family welfare all have significant contribution to economic growth.

Further, the development of transportation system does not only increase economic value, but also covers a socioeconomic system. If development policy and strategy tend to focus in human capital issues, development is needed to involve better balance with physical capital issues. Development cannot happen without interaction between human capital and physical capital. Economic activity cannot happen without infrastructure development. In this case transportation development and transportation sectors are important components in economy and tools used for economic development and growth and even to improve the competitiveness of a country (Rajagukguk 2020). In addition, infrastructure has positive impact on economic growth in the long run (Canning\&Pedroni2004). It was found that telephone and electricity can generate capacity and paved roads can produce a higher than average economic growth in a number of countries.

The importance of transportation is increasing in global economy where economic opportunities has increased sharply regarding human, goods, and information and information technology mobility. The relationship between quality and quantity of transportation and economic development becomes more real. Transportation infrastructure with high density and the quality of transportation quality are associated with high economic development. When transportation system is efficient and covers all regions in an economy it provides economic and social opportunities and the its benefit creates positive multiplier effect.

Transportation can create better accessibility to market, employment opportunity, and investment.Transportation reduces or eliminates high cost economy and also removes low quality of life. Efficient transportation eradicates costs in economic sectors.

Therefore, it can be said that transportation is the main driver of all economic sectors in a country to boost economic activity and promote a commodity and geographical area [5]. The Government of China implements the Silk Road Economid Belt (SREB) strategy as a strategy in industrial sustainable development through transportation infrastructure development in developing its economy [6]. Meanwhile, [7] analyzed the inequality in economic development in China employing the total factor productivity in the analysis of productivity and resource use efficiency. There was great inequality between eastern region which was relatively more effective compared to western region in China. The results of the study show that this inequality mainly caused by the technical inefficiency. One solution was transportation infrastructure development.

Indonesia is the largest maritime country in world, spread from Sabang in the west to Merauke in the eastwith more than 17 thousand island and area of around 7.81 million $\mathrm{km} 2$ ( 3.25 million $\mathrm{km} 2$ is sea and 2.55 million $\mathrm{km} 2$ is land). The President, Joko Widodo made sea toll road program as excellent government program. With this program, it is expected that transportation will connect islands and commodities to improve economic growth and 
welfare of Indonesians. In this study, the relationship between land transportation and economic growth was studied as sea toll road transportation are in the construction process.

Infrastructure development in particular electrification has generated income in rural areas [8]. There was two-way causality between electricity consumption and economic growth in South Africa [9]. Electrification also significantly increased employment agreement in South Africa [10]. Electrification significantly rose female and male work hours and income. Household electrification improved employment opportunity by releasing women from production home and enabled small and medium industries.

[11] carried out a study on the role of energy in economic growth. It was proposed that energy scarcity caused strong barrier in economic growth. When energy is enough, the effect on economic growth barrier is reduced. Economic growth barrier declines more if energy becomes more available.

[12] emphasized that health is one main priorities and relates to a number of other goals. A number of main challenges include to reduce maternal and child mortality, improve nutrition, improve further progress to combat infectious diseases including COVID-19, HIV/AIDS, tuberculosis, malaria, tropical diseases, and hepatitis. Noncommunicable diseases and risk factors, such as tobacco use, mental health problem, road accident, environmental health issues also need to be prevented continuously.

Further, data on safe sanitation and water and air quality show that the world need to reduce its risks on health. Bad health system is the main obstacle in a number of countries that has resulted in deficiency in health services. Meanwhile, global healthcare expenditure is increasing because of the increase of ageing patients with multiple comorbidities. In addition, the number of health workers declines sharply. Many employment opportunities in health for nurses and midwives are not utilized (Bayliss-Pratt, Daley, \&BhattacharyaCraven 2020). There is a very great deficiency in health workers, in particular nurses and midwives in Southeast Asia and Africa [13].

Nurses and midwives play a critical role in health improvement, disease prevention, and primary and community care delivery. Nurses and midwives provide first aid in emergency situation and are the key to universal health coverage. In addition, investment in education, job creation, and social sectors can result in a triple return, that is health outcome, global health security, and inclusive economic growth.

Do the physical capital development (availability of asphalt road andhousehold access to safe sanitation)and health human capital development (midwife) influence economic growth in districts in Indonesia? This study aims to examine the effects of the availability of asphalt road, household access to safe sanitation, and midwives on economic growth in districts in Indonesia.

\section{Data and methods}

The data source of this study was from the Indonesia Database for Policy and Economic Research (INDO-DAPOER) of the World Bank [14].The data covered 331 districts in Indonesia in 2005, 2008, and 2011. The time reference was based on the availability of data for each district. The response variable was the total GDP excluding oil and gas (in IDR million constant price). Meanwhile, the covariates were the villages with asphalt road (in \% of total villages), household with access to safe sanitation (in $\%$ of total households), and the number of midwives. 


\section{Methods}

The data in this study were analyzed employing univariate, bivariate, and multivariate analyses. Summary statistics of variables in the study and scatter diagrams between the covariates and response variable were given for univariate and bivariate analyses respectively. A multiple regression analysis was carried out to examine the effects of the percentage of villages with asphalt road, the percentage of householdswith access to safe sanitation, and the number of midwives on GDP. Excel and SPSS 25 were used in data processing.

\section{Results}

The results of univariate analysis are presented in Table 1 . These are the summary statistics of the variables in the study and include the number of observations ( $n$ ), minimum, maximum, mean, and standard deviation. It can be seen the number of observations was 993 for the three years, that is 2005, 2011, and 2018. The total GDP excluding oil and gas (in IDR million constant price) varied between 19,460 and 421,246,156. Meanwhile, the percentage of villages with asphalt road ranged from only 0.8 and 100.0, the percentage of householdswith access to safe sanitation differed between only 4.5 and 96.4, and the number of midwives varied between only 11 and 26,584.

Table 1. Summary statistics of variables in the model: Indonesia 2005, 2011, and 2018 (Source: [15], Author's compilation).

\begin{tabular}{|l|c|c|c|c|c|}
\hline \multicolumn{1}{|c|}{ Variable } & $\boldsymbol{n}$ & Minimum & Maximum & Mean & $\begin{array}{c}\text { Standard } \\
\text { deviation }\end{array}$ \\
\hline $\begin{array}{l}\text { Total GDP excluding } \\
\text { oil and gas (in IDR } \\
\text { million constant price) }\end{array}$ & 993 & $19,460.0$ & $421,246,156.3$ & $6,290,345.5$ & $25,000,280.1$ \\
\hline $\begin{array}{l}\text { Villages with asphalt } \\
\text { road(in \% of total } \\
\text { village) }\end{array}$ & 993 & 0.8 & 100.0 & 66.53 & 27.26 \\
\hline $\begin{array}{l}\text { Household access to } \\
\text { safe sanitation (in \% } \\
\text { of total household) }\end{array}$ & 993 & 4.5 & 96.4 & 60.19 & 17.15 \\
\hline Number of midwives & 993 & 11.0 & $26,584.0$ & 452.60 & $1,585.07$ \\
\hline
\end{tabular}

The results of bivariate analyses are displayed in Figure $1-3$. It can be seen from Figure 1 that in districts in Indonesia, the percentage of villages with asphalt road was positively correlated with GDP. It means the higher the percentage of villages with asphalt road the higher the GDP. An increase of one percent in the percentage of villages with asphalt road is correlated with an increase in GDP by 89,846 million IDR.

Figure 2 shows that the percentage of householdswith access to safe sanitation was positively related to GDP in districts in Indonesia. It means the higher the percentage of householdswith access to safe sanitation the higher the GDP. An increase of one percent in the percentage of householdswith access to safe sanitation is related to an increase in GDP by 7,077 million IDR.

Figure 3 displays that the number of midwiveshad positive relationship with GDP in districts in Indonesia. It means the higher the number of midwives the higher the GDP. An increase of one midwife is related to an increase in GDP by 8,167 million IDR. 


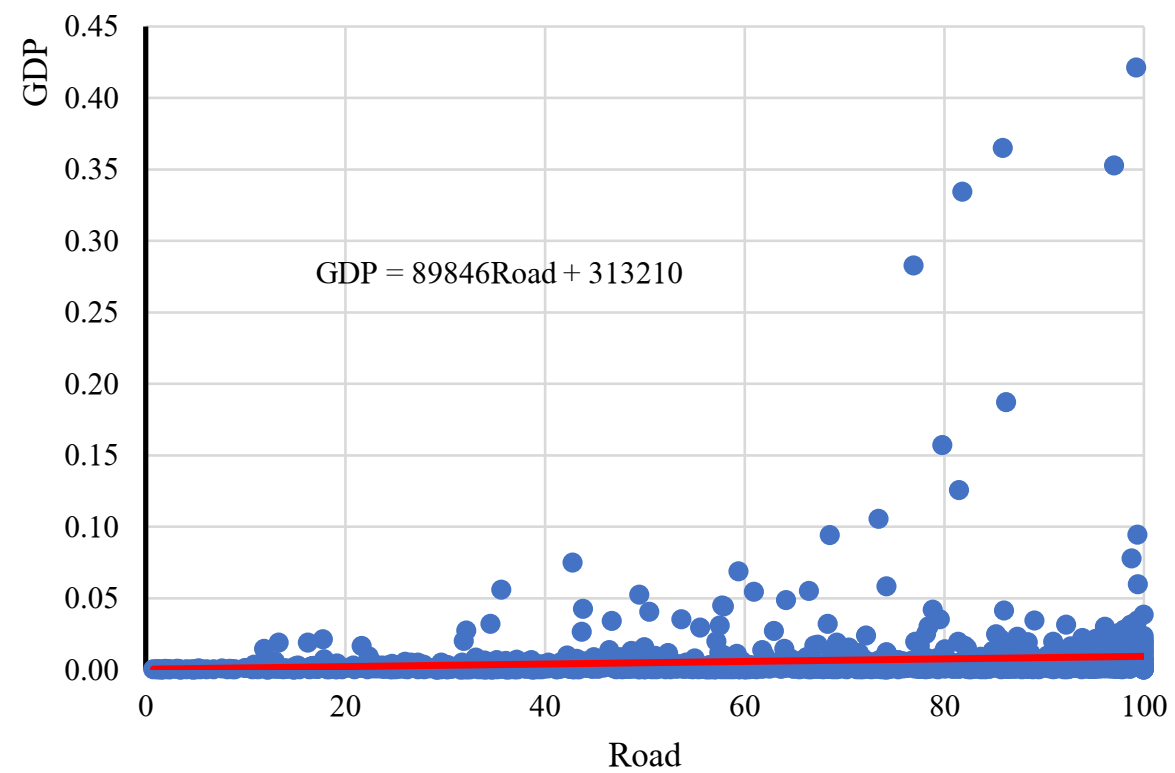

Fig. 1. Villages with asphalt road(in \% of total villages) and total GDP excluding oil and gas (in IDR million constant price): Indonesia 2005, 2011, and 2018 (Source: [14], Author's compilation).

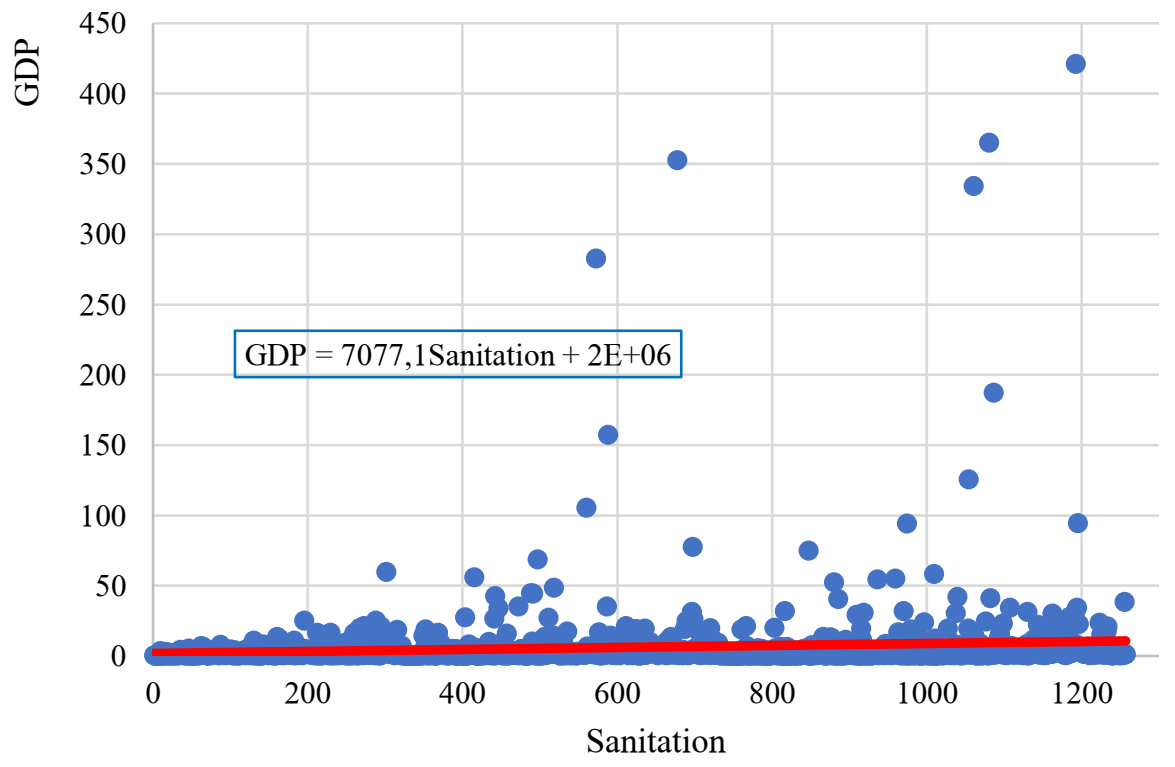

Fig. 2. Household access to safe sanitation (in \% of total households) and total GDP excluding oil and gas (in IDR million constant price): Indonesia 2005, 2011, and 2018 (Source: [14] Author's compilation). 


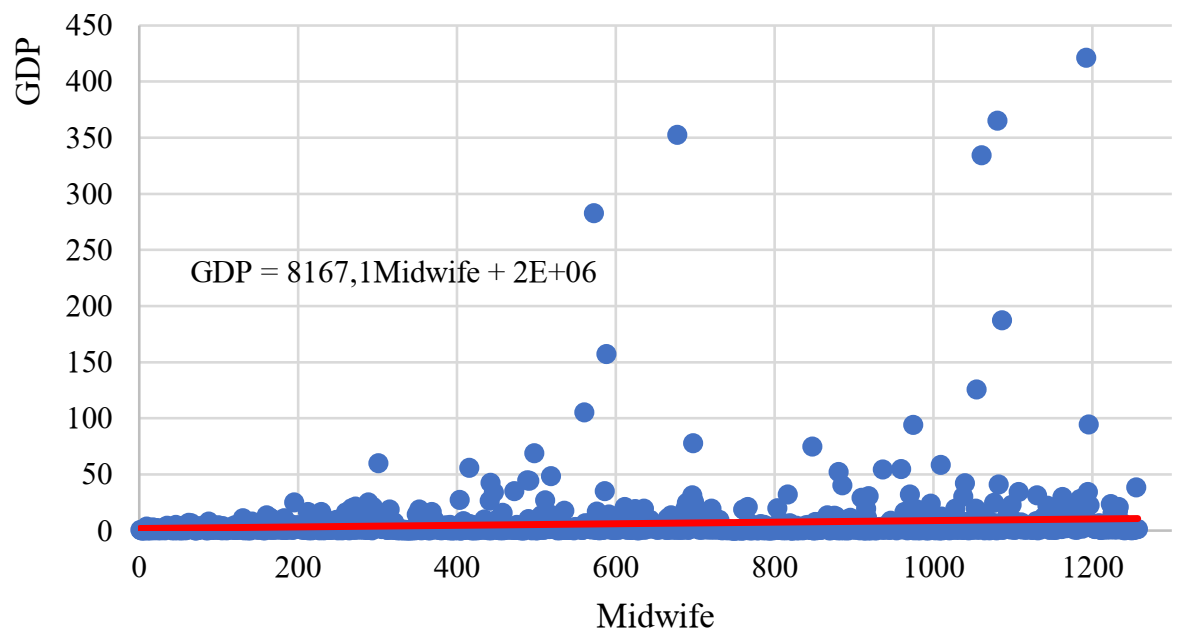

Fig. 3. Number of midwive and total GDP excluding oil and gas (in IDR million constant price): Indonesia 2005, 2011, and 2018 (Source: [14], Author's compilation).

Multivariate analysis results are given in Table 2. These comprise the coefficients, standard error, $t$, and signigicance of multiple regression model of the determinants of GDP. It can be seen that the percentage of villages with asphalt road, the percentage of householdswith access to safe sanitation, and the number of midwives is statistically and significantly associated with GDP in districts in Indonesia in 2005, 2011, and 2018.

The percentage of villages with asphalt roadis positively associated with GDP and significant at the 0.01 significance level. Other things being the same, on average, an increase of one percent in percentage of villages with asphalt roadwill increase GDP by 64,385 million IDR. In this study, the percentage of villages with asphalt roadwas the second strongest factor of GDP.

The percentage of households with access to safe sanitation has positive association with GDP at the 0.05 significance level. After controlling for other factors, on average, an increase of one percent in the percentage of householdswith access to safe sanitation is associated with an increase in GDP by 86,121 million IDR. In this study, the percentage of householdswith access to safe sanitationwas the third strongest factor of GDP.

The number of midwives associates positively with GDP at the less than 0.001 significance level. Ceteris paribus, on average, an increase of one midwife is associated with an increase in GDP by 9,884 million IDR. In this study, the number of midwives was the strongest factor of GDP.

Table 2. Coefficient, standard error, $t$, and significance of multiple regression model of the determinants of total GDP: Indonesia 2005, 2008, and 2011(Source: [14,15] Author's compilation).

\begin{tabular}{|l|c|c|c|c|}
\hline \multicolumn{1}{|c|}{ Variable } & Coefficient & $\begin{array}{c}\text { Standard } \\
\text { error }\end{array}$ & $\boldsymbol{t}$ & Significance \\
\hline Constant & $-7,651,375.2$ & $2,142,026.5$ & -3.572 & 0.000 \\
\hline $\begin{array}{l}\text { Villages with asphalt road } \\
\text { (in \% of total villages) }\end{array}$ & $64,382.3$ & $21,037.0$ & 3.060 & 0.002 \\
\hline $\begin{array}{l}\text { Household access to safe } \\
\text { sanitation (in \% of total } \\
\text { households) }\end{array}$ & $86,121.4$ & $33,461.6$ & 2.574 & 0.010 \\
\hline Number of midwives & $9,883.9$ & 343.7 & 28.753 & $<0.001$ \\
\hline
\end{tabular}




\section{Conclusions}

The results of this study confirm the importance of road infrastructure in villages, household access to safe sanitation, and the availability of midwives in boosting economic growth in districts in Indonesia. The availability of asphalt road can accelerate the movement and trade of goods and services across districts and hence promote economic growth. In addition, better household access to safe sanitation can representbetter development in a district that can result in healthier population who are more likely to work more productively to support economic development. Further, the availability of midwife in a district can also suggest healthier population that are advantage for economic activities. Therefore, the district governments should improve their effort to enhance the availability of asphalt road, household access to safe sanitation, and midwives in order to foster their economies.

\section{References}

1. T. Palei, Procedia Econ. Financ. (2015) https://doi.org/10.1016/s2212-5671(15)003226

2. O.B. Samosir, W. Rajagukguk, Regional Competitiveness and National Economic Growth (2017) https://doi.org/10.4018/978-1-5225-3856-1.ch016

3. H.T. Mai et al., International J. of Recent Technology and Engineering 8(2.11), 38763882 (2019)

4. E. Andreeva et al., Actual Problems of Economics 183(9), 220-227 (2016)

5. M. Mengistu, Int. J. Sci. Eng. Res. 10(11) (2016)

6. A.H. Tran et al., International J. of Recent Technology and Engineering 8(2.11), 38833888 (2019)

7. S.G. Chan, Int. J. Trade, Econ. Financ (2012) https://doi.org/10.7763/ijtef.2012.v3.218

8. P. Cook, Energy Sustain. Dev. (2011) https://doi.org/10.1016/j.esd.2011.07.008

9. N. Odhiambo, Energy Econ. (2009) https://doi.org/10.1016/j.eneco.2009.01.005

10. T. Dinkelman, Am. Econ. Rev. (2011) https://doi.org/10.1257/aer.101.7.3078

11. D. Stern, Ann. N. Y. Acad. Sci. (2011) https://doi.org/10.1111/j.17496632.2010.05921.x

12. World Health Statistics - Monitoring Health For The SDGs. World Heal. Organ (WHO, 2016)

13. WHO 2018. Nursing and midwifery key facts

14. World Bank 2021. The Indonesia Database for Policy and Economic Research, https://databank.worldbank.org/source/indonesia-database-for-policy-and-economicresearch

15. Statistics Indonesia 2021, https://www.bps.go.id/indikator/indikator/ view_data_pub/0000/api_pub/38/da_01/1 